\begin{tabular}{|l|l|l|}
\hline \multicolumn{2}{|c|}{ PublisherInfo } \\
\hline \hline PublisherName & $:$ & BioMed Central \\
\hline \hline PublisherLocation & $:$ & London \\
\hline \hline PublisherImprintName & $:$ & BioMed Central \\
\hline \hline
\end{tabular}

\title{
Mapping replication origins
}

\begin{tabular}{|l|l|l||}
\hline \multicolumn{2}{|c|}{ ArticleInfo } \\
\hline \hline ArticleID & $:$ & 3569 \\
\hline \hline ArticleDOI & $:$ & $10.1186 /$ gb-2000-1-1-reports035 \\
\hline \hline ArticleCitationID & $:$ & reports035 \\
\hline \hline ArticleSequenceNumber & $:$ & 60 \\
\hline \hline ArticleCategory & $:$ & Paper report \\
\hline \hline ArticleFirstPage & $:$ & 1 \\
\hline \hline ArticleLastPage & $:$ & 4 \\
\hline \hline & & RegistrationDate : 2000-2-20 \\
ArticleHistory & $:$ & Received \\
& & OnlineDate $\quad: 2000-2-20$ \\
\hline \hline ArticleCopyright & $:$ & BioMed Central Ltd2000-11 \\
\hline \hline ArticleGrants & $:$ & \\
\hline \hline ArticleContext & $:$ & 130591111 \\
\hline \hline
\end{tabular}




\section{Shuba Gopal}

\section{Abstract}

A new technique for the selection of newly synthesized DNA has enabled the selection and amplification of putative origins of replication on the human $\mathrm{X}$ chromosome.

\section{Significance and context}

The replication of the genome that precedes cell division consists of a tightly orchestrated series of events, starting with the initiation of DNA replication and ending with the generation of sister chromatids. Cells must have a way of ensuring that replication of the entire genome occurs once and only once per cell division. Most organisms seem to regulate this aspect of replication by limiting the start of DNA replication to one or a few sites on each chromosome. The initiation of DNA replication from these sites, the origins of replication, is well understood in most prokaryotes and in simple eukaryotes such as Saccharomyces cerevisiae. Very little is known about the initiation of replication in higher eukaryotes, however. To address this question, Rivella et al. outline a new strategy for identifying putative replication origins (PROs), and identify several PROs in a stretch of the human X chromosome.

\section{Key results}

To identify origins of replication on the human X chromosome, Rivella et al. isolated newly synthesized DNA (nsDNA) by selecting only small DNA fragments labeled during a pulse of bromodeoxyuridine (BrdU). The authors used PCR to amplify newly synthesized DNA (nsDNA) from human female HL60 cells and lymphocytes activated with phytohemagglutinin. Hybridization of the nsDNA fragments with genomic DNA cosmids spanning a gene-rich region of 500 kilobase pairs $(\mathrm{kbp})$ of the X chromosome identified nearly twenty sites at which nsDNA hybridizes preferentially, making these putative origins of DNA replication. The identified PROs were clustered in about $200 \mathrm{kbp}$, within or close to highly transcribed genes. No PROs were found in silenced loci or in loci for tissue-specific genes, such as genes involved in color pigmentation of the retina, that are not expressed in the cell lines used in this experiment. Rivella et al. also provide evidence supporting previous reports that replication of the inactivated $\mathrm{X}$ chromosome in females lags behind replication of the active $\mathrm{X}$ chromosome. By analyzing the corresponding PRO regions in the inactivated $\mathrm{X}$ chromosomes of their cell lines, the authors demonstrated that PROs on the inactive X chromosome do not appear to be functional, at least 
for the 2 hours of their experimental observations. As the authors themselves admit, however, this does not preclude PRO activity in the inactive X later in chromosome replication.

\title{
Methodological innovations
}

Although Rivella et al. used standard PCR techniques, they made some modifications to the protocol to enable them to amplify the newly synthesized DNA of interest. Newly synthesized DNA was labeled with BrdU, extracted from synchronized cell lines and size-fractionated. DNA fragments of $1 \mathrm{kbp}$ or less were selected for PCR amplification with two primers - a degenerate primer with broad specificity to sequences within the $500 \mathrm{kbp}$ region and a primer with fewer degenerate oligonucleotides. Two cycles of amplification were necessary, as insufficient DNA for analysis could be recovered from the sizefractionation step alone. The amplified nsDNA was then hybridized to biotin-labeled genomic DNA cosmids that spanned a $500 \mathrm{kbp}$ region on the chromosome. The hybridized regions were again amplified by PCR using another set of degenerate primers. The hybridization, washing and amplification steps were repeated twice, in order to ensure recovery of biologically relevant sequences. These were then sequenced and analyzed in the standard manner.

\section{Reporter's comments}

Although the authors go to great pains to ensure that PCR artifacts are not skewing their results, it remains an issue, particularly as there are four, independent, PCRs at various points in the process. Nevertheless, their method for identifying origins of replication in a large region of the human genome is inventive, and their finding that these sites cluster around actively transcribed genes is intriguing. Their discovery will certainly lead to speculation on the purpose of this organization of the DNA.

\section{Table of links}

\author{
Genomics
}




\section{References}

1. Rivella S, Palermo B, Pelizon C, Sala C, Arrigo G, Toniolo D: Selection and mapping of replication origins from a $500 \mathrm{kbp}$ region of the human $\mathrm{X}$ chromosome and their relationship to gene expression. Genomics. 1999, 62: 11-20. 0888-7543

This PDF file was created after publication. 